\title{
Robin Williams' suicide: a case study
}

\author{
O suicídio de Robin Williams: estudo de caso
}

Hassaan Tohid*

\begin{abstract}
Introduction: The world renowned comedian and four-time Oscar nominated actor Robin Williams died on August 11, 2014. From the outset, the news indicated that his death was believed to be a suicide and this was later confirmed to be true by the autopsy reports. Williams had been suffering from severe depression, which is believed to be the leading contributor to his suicide. In this case study, I will highlight the event of the actor's suicide and the main risk factors along with depression leading to his tragic death. As of the end of 2015, no other case study seemed to have addressed or explored the links between the cause (or causes) and events leading to Robin Williams' suicide.

Case description: Robin Williams was suffering from relationship problems, financial problems, drug addiction, and major depression. All of these factors led to his suicide.

Comments: The chances of committing suicide drastically increase in the presence of any of the key risk factors. Unfortunately, the actor Robin Williams was dealing with four of the major risk factors all together, which put him at a high risk of committing suicide and eventually led to his tragic death.

Keywords: Suicide, addiction, suicidal ideation, dementia, Lewy body, addiction suicide.
\end{abstract}

\section{Introduction}

By definition, "The act of deliberately taking one's own life or causing one's own death" is referred to as "suicide." Various causes of suicide have been studied, including mental disorders like depression, bipolar

\section{Resumo}

Introdução: $O$ ator Robin Williams, comediante reconhecido internacionalmente e quatro vezes indicado ao Oscar, faleceu no dia 11 de agosto de 2014. Desde o início, os noticiários indicavam que sua morte provavelmente resultara de suicídio, e isso foi confirmado posteriormente nos relatórios da autópsia. Williams vinha sofrendo de depressão severa, a qual, acredita-se, foi o fator que mais contribuiu para seu suicídio. Neste estudo de caso, vou discorrer sobre o suicídio do ator e sobre os principais fatores de risco, além da depressão, que levaram à sua morte trágica. Do final de 2015 para cá, nenhum outro estudo de caso parece ter abordado ou explorado as associações entre a causa (ou as causas) e os eventos que levaram ao suicídio do ator Robin Williams. Descrição do caso: Robin Williams vinha sofrendo com problemas de relacionamento, problemas financeiros, abuso de drogas e depressão severa. Todos esses fatores levaram ao seu suicídio. Comentários: As chances de cometer suicídio aumentam drasticamente na presença de qualquer fator de risco chaves. Infelizmente, 0 ator Robin Williams estava exposto a quatro fatores de risco chaves simultaneamente, colocando-o sob um alto risco de cometer suicídio, o que eventualmente culminou com sua trágica morte.

Descritores: Suicídio, adição, ideação suicida, demência, corpos de Lewy, suicídio por adição.

disorder, schizophrenia, borderline personality disorder ${ }^{1}$ alcoholism, and drug abuse. ${ }^{2}$ The most commonly used methods of suicide include hanging, pesticide poisoning, and firearms. In the year 1990, 712,000 deaths were reported to be suicides, while by 2013 this number

* Center for Mind \& Brain, University of California, Davis (UC Davis), CA, USA.

Financial support: none.

Submitted Oct 06 2015, accepted for publication Mar 26 2016. No conflicts of interest declared concerning the publication of this article .

Suggested citation: Tohid H. Robin Williams' suicide: a case study. Trends Psychiatry Psychother. 2016;38(3):178-182. http://dx.doi.org/10.1590/2237-60892015-0064 
had jumped to $842,000 . .^{3}$ According to the Centers for Disease Control and Prevention there were 39,518 suicides in the United States in the year 2011 alone. $^{4}$ However, this number jumped to 43,361 in 2012.5 Suicide is the 10 th leading cause of death worldwide. ${ }^{2,6}$ Men commit suicide more frequently than women, with rates three to four times the rates among females in any given year. $^{7}$

According to one estimate, there are ten to twenty million non-fatal attempted suicides every year. ${ }^{8}$ Nonfatal suicide attempts may lead to injury and permanent or long-term disabilities. Attempts are more common among young people and females. However, successful attempts are more prevalent among males. Therefore, it is a clinical challenge to save patients at risk from committing suicide. Neither celebrities nor politicians are safe from this cause of death. The suicide of the famous Oscar-winning actor Robin Williams (like many other "celebrities" before him) is one example of how famous people are not immune to suicidal impulses.

On August 11th 2014, movie fans in the United States and across the world were stunned when various TV channels broadcast, and internet news websites posted, the sad news that Robin Williams, the famous Hollywood actor and comedian, had died. ${ }^{9}$ At the time of his death, he was 63 years old. ${ }^{10}$ Robin McLaurin Williams was born on July 21st, 1951 at St. Luke's Hospital'11 in Chicago, Illinois. He was born into a family in which the father, Robert Fitzgerald Williams, was a senior executive of Ford Motor Company's Lincoln-Mercury Division and the mother, Laurie McLaurin, was a former model from Jackson, Mississippi. ${ }^{12-14}$ Williams chose a career in acting and later went on to become one of the most renowned actors Hollywood has ever produced.

The majority of people who attempt suicide usually suffer from major depression. Less than four percent of these eventually take their lives. The percentage of all depression sufferers who successfully commit suicide is very low, so what triggered Robin Williams' suicide? Was it just depression, or did a combination of problems lead to his suicide? This case study will highlight the event of the superstar's death and the factors leading to his death.

\section{Case description}

\section{Events leading to suicide}

It is reported that Williams became addicted to cocaine during the late 1970 s and early 1980 s. ${ }^{15,16} \mathrm{He}$ quit cocaine after a friend's demise. However, this event led Robin Williams to major depression, which is thought be a leading cause of his death. Williams' depression was well known to his fans because he repeatedly mentioned his depression during interviews. Robin publicly acknowledged his depression and anxiety in an interview with the Guardian newspaper. ${ }^{16}$ In 2003, he was admitted to a substance-abuse rehabilitation center in Newberg, Oregon, to deal with his alcohol addiction. ${ }^{16}$ His substance use, his depression, and his health were sporadically in the news over the years. Williams' health was once again in the news when, in March 2009, he was hospitalized because of heart problems and had aortic valve replacement surgery. ${ }^{17,18}$

A few months before his death in 2014, he was admitted to the Hazelden Foundation Addiction Treatment Center in Lindstrom, Minnesota, for alcohol-related problems. ${ }^{19}$ Furthermore, fighting two divorces with two of his ex-wives not only proved to be emotionally and psychologically stressful, but was also an immense financial burden for the superstar. Divorce settlements cost him more or less tens of millions of dollars according to one estimate. This led to financial problems, which itself is a contributing risk factor leading to depression and suicide. He had to sell his 29.9 million dollar 640acre ranch in Napa, California, which he had owned for more than ten years. Furthermore, another trigger for his depression was when CBS announced that his series, "The Crazy Ones," would not get a second season. Robin's close friends claimed that this news was emotionally draining for Williams. This happened a little after his famous heart surgery, further aggravating his symptoms of depression. ${ }^{20}$

\section{The suicide}

Williams committed suicide on Monday, August 11, 2014, at his home in Tiburon, Paradise Cay, California. ${ }^{21}$ An initial report stated Williams had apparently hanged himself with a belt and died from asphyxiation. ${ }^{22-24}$ It was revealed following his death that he had recently been diagnosed with Parkinson's-like symptoms. These symptoms triggered his anxiety, restlessness and possibly sleep-talking, which forced him to sleep in a different room from his wife Susan, further aggravating his pre-existing depressive symptoms. ${ }^{25}$

Three months later, in November of 2014, Williams' autopsy reports were revealed. The autopsy confirmed that Williams' death was caused by asphyxiation and hanging, which was most probably due to an attempted suicide. ${ }^{25}$ Toxicology reports confirmed anti-depressants, caffeine, and levodopa in his body, but at therapeutic dose levels, which indicated that he did not deliberately overdose himself to commit suicide. The actor's wife 
Susan reported that along with severe depression he had recently been diagnosed with Parkinson's disease. A medical history taken by authorities revealed that he also had recent symptoms of paranoia and hallucinations. ${ }^{26}$

According to the actor's wife, his pre-suicide activities included placing some wrist watches in a sock and dropping them off to keep them safe, ${ }^{27}$ which could be considered bizarre behavior. At 7:09 p.m. on the night before his demise he called his wife to tell her that he was buying magazines for her at a bookstore. He returned home fine and handed the magazines to her. He then spent some time searching through their closet, grabbed his iPad and left the room at 10:30 p.m., which is when his wife saw him last. She left the house the next morning assuming he was still sleeping. At around 11:45 a.m., William's assistant became worried due to his lack of response to text messages and phone calls and later found him hanging by a nylon belt in a closet door frame wearing a long black T-shirt and belted black jeans slightly suspended in a seated position, with superficial cut marks on the inside of his left wrist; with rigor mortis evidently visible. He was pronounced dead at 12:02 p.m. on Monday. ${ }^{26}$

Williams' body was found in an empty bedroom belonging to his stepson. Personal items were present near the body, placed on a chair, which included an iPad and two anti-depressants: Mirtazapene and Seroquel. Besides these, a pair of black sneakers and a pocketknife were found, which was from his personal gift collection, with a dried red substance that was later confirmed to be Williams' blood. ${ }^{26}$ dry blood on the knife and the cut marks on the wrists could be an indicator of past attempts of suicide, which is by far the strongest indicator for suicide risk. ${ }^{28}$ Even one year after a suicide attempt, risk of suicide and death due to other causes is a high possibility. ${ }^{29}$

However, whether this past attempt was right before the actual successful attempt or was a few days before the death remains unknown. His iPhone and wallet were found in his pockets.

Williams' assistant and his wife confirmed that despite a long history of severe depression he had never expressed suicidal thoughts or behavior. His pill box had been refilled the day before, but the medications remained intact in daily spots which showed lack of medication compliance. A search of his iPad revealed information about medications in his browsing history and no search results related to suicide or hanging. The telephone revealed no hint of him being suicidal. ${ }^{26}$

Investigators revealed that there were no reflective devices or pornography near the body and no history of autoerotic asphyxia according to his wife. However, an unknown person interviewed stated that Williams had worked on a movie some years earlier in which his character's son accidentally died by autoerotic asphyxiation and the scene was very difficult and emotionally stressful for Williams and he may have researched hanging during filming. Later, an investigator revealed that he had watched the movie - a dark comedy called World's Greatest Dad - and found that (in the movie) the character's son was found seated on the floor, learning forward with a ligature around the neck secured by a belt - very similar to the position Williams' body was found after the death. ${ }^{26}$

\section{The actual cause}

The final autopsy report, released in November 2014, affirmed that Williams had committed suicide as initially described; neither alcohol nor illegal drugs were involved, while any prescription drugs present in Williams' body were at "therapeutic" levels. The report also included that Williams had been suffering from a recent increase in paranoia. ${ }^{25}$

An examination of his brain tissue found Lewy bodies indicating "diffuse Lewy body dementia" which manifests with Parkinsonism symptoms. ${ }^{30}$ Williams' doctors believe that Lewy body dementia "was the critical factor" that led to his suicide. ${ }^{31}$

Williams' wife Susan stated that in the period before his death, he was sober, but that he had been diagnosed with early stage Parkinson's disease, which was something he was "not yet ready to share publicly." 32,33

The above case description clearly shows that the actor was indeed suffering from major depression, substance abuse including alcohol addiction, relationship troubles, financial problems, and newly-diagnosed Lewy body dementia. All of these problems, except Lewy body dementia, have been described as risk factors for suicide. A significant psychiatric problem such as severe depression is often found in people who die by suicide or attempt suicide. In addition to depression, alcohol abuse is also considered as one of the most common disorders associated with suicidal behavior. The lifetime risk of suicide is usually around $4 \%$ in people suffering from mood disorders. ${ }^{34}$ This percentage increases to $7 \%$ in alcohol dependence, ${ }^{35}$ to $8 \%$ in bipolar disorder, ${ }^{36,37}$ and is $5 \%$ in psychosis and schizophrenia. ${ }^{38}$

This risk of suicidal behavior increases with a comorbid condition; for example, patients with depression and psychosis at the same time are more likely to commit suicide than patients with depression alone. ${ }^{39}$ The case description also mentions paranoia as one of the actor's symptoms, which does point toward an undiagnosed psychosis and if this were the case it would further aggravate the chances of committing suicide. 
All kinds of substance abuse disorders increase the chances of a person committing suicide. ${ }^{40}$ Alcohol and other substance abuse disorders are actually involved in $25-50 \%$ of all suicides. ${ }^{35}$ Likewise, the risk is further aggravated if alcohol or substance use is present together with other psychiatric disorders. Other substances, including cannabis, heroin or nicotine also increase the risk factor for suicide. ${ }^{41}$ Unfortunately, Williams also had a history of having used another substance, cocaine. Financial instability further increases the risk of suicide, especially when coexisting with other risk factors such as depression, anxiety, violence, and alcohol abuse. ${ }^{42,43}$

I believe incidents like these can be prevented. Research evidence suggests that family and friends can be a significant source of emotional, social, and financial support and can be helpful in neutralizing the stressor's effect. ${ }^{44}$

Certain other factors such as religiosity, spirituality, or faith, have been found to be useful in helping people with suicidal ideation. ${ }^{45}$ People who take religious support to deal with their stress usually find a way to bring their lives back on track rather than choosing suicide as a solution.

Furthermore, personal well-being and positive coping strategies help reduce the chance of committing suicide. ${ }^{46}$

\section{Conclusion}

Depression affects about 16 million people in the United States, according to the National Institutes of Mental Health, and more than 350 million globally, according to the World Health Organization, and it is a result of interacting social, biological, and environmental factors. It can be a risk factor for suicide. ${ }^{47}$ Alcoholism and drug abuse are also prevalent in society and are among the first few leading causes of suicide. ${ }^{48,49}$ Moreover, financial and relationship problems are also considered risk factors for depression and suicides. ${ }^{50,51}$ Unfortunately, all of these risk factors or contributors to suicidal behavior were present in the legendary actor Robin Williams' life.

A careful examination of the life of the apparently pleasant, funny, and happy Robin Williams indicates that he was indeed suffering from major depression, alcoholism, drug abuse, financial problems, serious relationship issues leading to multiple divorces, and Lewy body dementia, all of which are considered risk factors leading to attempted and successful suicide. In this case, a combination of all these factors, or the comorbid condition of such severity, even though not apparent to the world, ultimately led to his suicide. His symptoms, as described, also point toward a possibility of acute psychosis, although this diagnosis remained unconfirmed.

In the 21st century, various countries have developed national strategies that involve commitment by their governments to prioritize and tackle the problem of death by suicide. These involve education and guidance about evidence-based suicide prevention methods. ${ }^{52}$ The United Nations has published "Prevention of suicide: guidelines for the development and application of national strategies". 53 Unfortunately, despite all these measures, the suicide rate continues to rise. Educating doctors, nurses and other clinicians to identify depression, other mental disorders, and substance abuse and performing comprehensive evaluations of suicide risk are vital measures for preventing suicide. Continuous psychiatric training of psychiatrists and non-psychiatric clinicians should be arranged over a number of years in order to fight with this clinical challenge. ${ }^{54}$

It is therefore recommended that patients, physicians, and psychiatrists should not take these risk factors lightly, but should take appropriate measures as soon as the symptoms of depression or alcoholism are observed in a patient, because these kinds of medical problems can be life threatening, as is evident from the case of the actor Robin Williams. Whether Lewy body dementia can trigger suicide, and whether it contributed to his suicide, is still a matter of debate and future studies may uncover this association.

\section{References}

1. Paris J. Chronic suicidality among patients with borderline personality disorder. Psychiatry Serv. 2002;53:738-42.

2. Hawton K, van Heeringen K. Suicide. Lancet. 2009;373:137281.

3. GBD 2013 Mortality and Causes of Death Collaborators. Global, regional, and national age-sex specific all-cause and causespecific mortality for 240 causes of death, 1990-2013: a systematic analysis for the Global Burden of Disease Study 2013. Lancet. 2015;385:117-71.

4. Lang B. Robin Williams: should Hollywood do more to help stars in dark places [Internet]?Variety. 2014 Aug 20.variety.com/2014/ biz/news/robin-williams-depression-hollywood-1201286154/

5. World Health Organization (WHO). Preventing suicide: a global imperative [Internet]. 2014. apps.who.int/iris/ bitstream/10665/131056/1/9789241564779_eng.pdf

6. Värnik P. Suicide in the world. Int J Environ Res Public Health. 2012;9:760-71.

7. Meier MB, Clinard RF. Sociology of deviant behavior. 14th ed. Belmont: Wadsworth Cengage Learning; 2008.

8. Bertolote JM, Fleischmann A. Suicide and psychiatric diagnosis: a worldwide perspective. World Psychiatry. 2002;1:181-5.

9. Itzkoff D. Robin Williams, Oscar-winning comedian, dies at 63 [Internet]. The New York Times. 2014. nytimes.com/2014/08/12/ movies/robin-williams-oscar-winning-comedian-dies-at-63. html?_r=1

10. Robin Williams dead at 63. CBS news [Internet]. CBS NEWS. 2014 Aug 11. cbsnews.com/news/actor-robin-williams-dead-at63-apparent-suicide/

11. Chicago native Robin Williams recalled 'good times' growing up here [Internet]. CBS Chicago. 2014 Aug 12 [cited 2014 Aug 18]. chicago.cbslocal.com/2014/08/11/chicago-native-robinwilliams-dead-at-63/ 
12. Rubenstein S. Laurie Williams - comedian's mother [Internet]. SF Gate. 2001 Sep 8. sfgate.com/news/article/Laurie-Williamscomedian-s-mother-2880676.php

13. Kornbluth J. Robin Williams's change of life: fighting for family in his new film, Mrs. Doubtfire, and in real life [Internet]. New York Magazine. 1993 Nov 22. https://books.google.com.br/books?id=a xsAAAAAMBAJ\&printsec $=$ frontcover\&hl $=$ pt-BR

14. Shipman R. Genealogy buffs find Williams' roots in Evansville [Internet]. The Washington Times.2014 Aug 13. washingtontimes. com/news/2014/aug/13/genealogy-buffs-find-williams-roots-inevansville/

15. Lipton J, Williams R. Inside the actor's studio. Season 7. Episode 710. Bravo. 2001 Jun 10.

16. Aitkenhead D. Robin Williams: 'I was shameful, did stuff that caused disgust - that's hard to recover from' [Internet]. The Guardian. 2010 Sep 20 [cited 2014 Aug 12]. theguardian.com/ film/2010/sep/20/robin-williams-worlds-greatest-dad-alcoholdrugs

17. Robin Williams comes clean on 'GMA. Interview with Diane Sawyer [Internet]. ABC News. 2006 Oct 2. abcnews.go.com/GMA/robinwilliams-clean-gma/story?id $=2515796$

18. Robin Williams to undergo heart surgery [Internet]. Today Celebrities. 2009 Mar 5. today.com/id/29518817/ns/today-today entertainment/t/robin-williams-undergo-heart-surgery/

19. Errico M. Robin Williams dead of apparent suicide at 63[Internet]. Yahoo! 2014 Aug 11. yahoo.com/celebrity/blogs/celeb-news/ robin-williams-dead-of-apparent-suicide-at-63-231414092.html

20. Rottenberg J, Kaufman A, Romney L. Robin Williams' friends saw signs he was succumbing to depression [Internet]. Los Angeles Times. 2014 Aug 13. latimes.com/entertainment/movies/la-etmn-robin-williams-last-days-20140813-story.html

21. Martin N. San Francisco neighbours mourn Robin Williams [Internet]. Sky News. 2014 Aug 13. news.sky.com/story/1317742/ san-francisco-neighbours-mourn-robin-williams

22. Itzkoff D, Fitzsimmons EG, Weber B. Robin Williams, oscar-winning comedian, dies at 63 [Internet]. The New York Times. 2014 Aug 11. nytimes.com/2014/08/12/movies/robin-williams-oscarwinning-comedian-dies-at-63.html?_r=0

23. Nordyke K, Byrge D. Robin Williams dies of suspected suicide [Internet]. The Hollywood Reporter. 2014 Aug 11. hollywoodreporter. $\mathrm{com} /$ news/robin-williams-dead-actor-dies-724724

24. Messer L. Robin Williams died in an apparent suicide by hanging [Internet]. ABC News. 2014 Aug 12. abcnews.go.com/ Entertainment/robin-williams-apparently-committed-suicidehanging/story? $\mathrm{id}=24947586$

25. Stucker M. Robin Williams' death ruled suicide [Internet]. CNN. 2014 Nov $11 . \quad$ cnn.com/2014/11/07/showbiz/robin-williamsautopsy/

26. Youn S. Robin Williams: autopsy confirms death by suicide . Nov/07/2014. Available from http://www.hollywoodreporter.com/ news/robin-williams-autopsy-confirms-death-746194

27. Rothkopf J. Autopsy: Robin Williams had Lewy body dementia [Internet]. 2014 Nov 13. salon.com/2014/11/13/autopsy_robin williams_had_lewy_body_dementia/

28. Yoshimasu K, Kiyohara C, Miyashita K; Stress Research Group of the Japanese Society for Hygiene. Suicidal risk factors and completed suicide: meta-analyses based on psychological autopsy studies. Environ Health Prev Med. 2008;13:243-56.

29. Beautrais AL. Subsequent mortality in medically serious suicide attempts: a 5 year follow-up. Aust N Z J Psychiatry. 2003;37:5959.

30. Dillon N. Robin Williams coroner's report finds no illegal drugs or alcohol in system [Internet]. Daily News. 2014 Nov 07. nydailynews.com/entertainment/gossip/robin-williams-coronerreport-no-drugs-alcohol-system-article-1.2003220

31. Robin Williams dementia hallucinations triggered suicide [Internet]. TMZ. 2014 Nov 11. tmz.com/2014/11/11/robinwilliams-dementia-lewy-body-parkinsons-suicide-death/

32. Robin Williams had Parkinson's when he died [Internet]. BBC News. 2014 Aug 14. bbc.com/news/world-us-canada-28796277

33. Ryder T. Wife: Robin Williams had Parkinson's disease, his sobriety intact before death [Internet]. Yahoo! 2014 Aug 15. cafemom.com/ group/115189/forums/read/20191046/Wife_Robin_Williams_ Had_Parkinsons_Disease_His_Sobriety_Intact_Before_Death_ ETA_Michael_J_Fox_commen
34. Bostwick JM, Pankratz VS. Affective disorders and suicide risk: a reexamination. Am J Psychiatry. 2000;157:1925-32.

35. Schneider B. Substance use disorders and risk for completed suicide. Arch Suicide Res. 2009;13:303-16.

36. Hawton KL, Sutton L, Haw C, Sinclair J, Harriss L. Suicide and attempted suicide in bipolar disorder: a systematic review of risk factors. J Clin Psychiatry. 2005;66:693-704.

37. Nordentoft M, Mortensen PB, Pedersen CB. Absolute risk of suicide after first hospital contact in mental disorder. Arch Gen Psychiatry. 2011;68:1058-64.

38. Palmer BA, Pankratz VS, Bostwick JM. The lifetime risk of suicide in schizophrenia: a reexamination. Arch Gen Psychiatry. 2005;62:247-53.

39. Cavanagh JT, Carson AJ, Sharpe M, Lawrie SM. Psychological autopsy studies of suicide: a systematic review. Psychol Med. 2003;33:395-405.

40. Beautrais AL, Joyce PR, Mulder RT, Fergusson DM, Deavoll BJ, Nightingale SK. Prevalence and comorbidity of mental disorders in persons making serious suicide attempts: a case-control study. Am J Psychiatry. 1996;153:1009-14.

41. Bohnert KM, Ilgen MA, McCarthy JF, Ignacio RV, Blow FC, Katz IR. Tobacco use disorder and the risk of suicide mortality. Addiction. 2014;109:155-62.

42. Chang SS, Stuckler D, Yip P, Gunnell D. Impact of 2008 global economic crisis on suicide: time trend study in 54 countries. BMJ. 2013;347:f5239.

43. Stuckler D, Basu S. The body economic: why austerity kills: recession, budget battles, and the politics of life and death. London: Penguin; 2013.

44. Sarchiapone M, Mandelli L, Iosue M, Andrisano C, Roy A. Controlling access to suicide means. Int J Environ Res Public Health. 2011;8:4550-62.

45. Van Praag $\mathrm{H}$. The role of religion in suicide prevention. In: Wasserman D, Wasserman C, editors. Oxford textbook of suicidology and suicide prevention: a global perspective. Oxford: Oxford University; 2009. p. 7-12.

46. Sisask M, Värnik A, Kolves K, Konstabel K, Wasserman D. Subjective psychological well-being (WHO-5) in assessment of the severity of suicide attempt. Nord J Psychiatry. 2008;62:431-5.

47. Wang SM, Hwang S, Yeon B, Choi KH, Oh Y, Lee HK, et al. Suicide risk assessments: which suicide risk factors psychiatric residents consider significant? Psychiatry Investig. 2015;12:324-9.

48. Martiniuk AL, Chen HY, Glozier N, Patton G, Senserrick T, Williamson $A$, et al. High alcohol use a strong and significant risk factor for repetitive self-harm in female and male youth: a prospective cohort study. Am J Drug Alcohol Abuse. 2015 Aug 5:1-9. [Epub ahead of print]

49. Yuodelis-Flores C, Ries RK. Addiction and suicide: a review. Am J Addict. 2015;24:98-104

50. Yip PS, Yousuf $\mathrm{S}$, Chan $\mathrm{CH}$, Yung $\mathrm{T}, \mathrm{Wu} \mathrm{KC}$. The roles of culture and gender in the relationship between divorce and suicide risk: a meta-analysis. Soc Sci Med. 2015;128:87-94.

51. Inoue K, Fukunaga T, Okazaki Y. Study of an economic issue as a possible indicator of suicide risk: a discussion of stock prices and suicide. J Forensic Sci. 2012;57:783-5.

52. WHO. Public health action for the prevention of suicide: a framework [Internet]. 2012 [cited 2014 Apr 23]. apps.who.int/ iris/bitstream/10665/75166/1/9789241503570_eng.pdf

53. United Nations. Prevention of suicide: guidelines for the formulation and implementation of national strategies. New York: United Nations; 1996.

54. Du Roscoät E, Beck F. Efficient interventions on suicide prevention: a literature review. Rev Epidemiol Sante Publique. 2013;61:36374

\section{Correspondence:}

Hassaan Tohid

Center for Mind \& Brain, University of California, Davis

3533 Valley View Court

94534 - Fairfield, CA - USA

E-mail: hassaantohid@hotmail.com 